\title{
MODEL BLENDED LEARNING DALAM MENINGKATKAN EFEKTIFITAS PEMBELAJARAN
}

\author{
Walib Abdullah \\ Institut Agama Islam (IAI) Al-Khairat Pamekasan \\ walibsamruec@yahoo.com
}

\begin{abstract}
In the 21 st century learning is already entered to the digital era , which is many educational practitioners have developed and designed a digital-based learning such as online learning. However Online learning still needs the other learning namely face-to-face learning. That is why Educational experts combine these two lessons mode into a new learning theory called by Blended Learning. Blended learning is a mixing or combination of online learning, offline learning, and face-to-face learning, in offline learning students can operate the learning sequence eventhough it is not connected to internet through the application program. Based on the researchs it prove that blended learning has an effect which is more effective rather than online learning or face-to-face learning in the result of students' learning. The use of blended learning may apply by using these following combination namely $50 / 50$ means that $50 \%$ is online and offline learning and 50\% is face to face learning, 75/25 means that $75 \%$ is online and offline learning and $25 \%$ is face to face learning, or $25 / 75$ means that $25 \%$ is online and offline learning and $75 \%$ is face to face learning from the learning period alocation. There are some cases need to be consideration in designing a blended learning, it is about how to make the learning is so interesting and suitable with the characteristic of students' learning style.
\end{abstract}

Kata kunci : Blended Learning, Online, Offline, Face to face.

\begin{abstract}
Abstrak
Abad 21 ini pembelajaran sudah masuk pada era digital, yang mana para praktisi pendidikan sudah banyak mengembangkan dan merancang pembelajaran dengan berbasis digital seperti misalnya pembelajaran online. Akan tetapi, pembelajaran online masih membutuhkan adanya pembelajaran lain yaitu pembelajaran tatap muka. Maka dari itu para ahli pendidikan menggabungkan kedua model pembelajaran tersebut dan menjadikannya sebuah teori pembelajaran baru yang disebut Blended Learning. Blended learning merupakan campuran atau penggabungan pembelajaran tatap muka (face to face), pembelajaran online dan pembelajaran offline, dalam pembelajaran offline siswa masih bisa mengoperasikan rangkaian pembelajaraan tersebut walaupun tidak terhubung dengan internet,
\end{abstract}


yaitu melalui program aplikasi. Berdasarkan beberapa penelitian disebutkan bahwa blended learning mempunyai dampak yang lebih efektif dari pada pembelajaran online ataupun pembelajaran tatap muka dari segi hasil belajar siswa. Penggunaan Blended learning bisa di terapkan dengan menggunakan kombinasi-kombinasi berikut 50/50 berarti $50 \%$ pembelajaran online dan offline $50 \%$ pembelajaran tatap muka , 75/25 yaitu 75\% pembelajaran online dan offline 25\% pembelajaran tatap muka, atau $25 / 75$ jadi $25 \%$ pembelajaran online dan offline $75 \%$ pembelajaran tatap muka dari alokasi waktu pembelajaran. Ada beberapa hal yang perlu dijadikan pertimbangan dalam mendisain blended learning, hal itu adalah bagaimana cara agar pembelajaran tersebut menarik dan sesuai dengan karakteristik gaya belajar siswa.

Kata kunci : Blended Learning, Online, Offline, Pembelajaran Tatap Muka

\section{Pendahuluan}

Pembelajaran yang diterapkan di berbagai sekolah masih banyak menggunakan pembelajaran tradisional yaitu masih menggunakan pembelajaran yang mengedapankan tatap muka antara guru dan siswa padahal didunia kerja ataupun dunia bisnis dihadapkan dengan kehidupan yang berbasis teknologi informasi dan komounikasi (TIK) yang memudahkan kita dalam berbagai urusan. Begitupula dalam pembelajaran dalam mentransfer ilmu banyak media yang memudahkan siswa untuk menjelahkan pengetahuan dan informasi yang dibutuhkan dalam dunia pendidikan.

Masalah utama adalah siswa ataupun guru masih rendah dalam penguasaan teknologi maka dari itu berbagai lembaga pendidikan di Indonesia masih menggunakan pembelajaran tradisional. Maka dari itu diharapkan lembaga pendidikan melakukan revolusi pembelajaran yang awalnya menggunakan pembelajaran tradisonal atau tatap muka maka berubah menjadi pembelajaran berbasis digital.

Perubahan pendidikan yang mana proses komunikasi dalam pendidikan sudah berpindah pada komunikasi bermedia dengan memanfaatkan teknologi digital tidak banyak lagi yang menggunakan komonikasi yang dikembangkan oleh beberapa ahli pendidikan seperti Hovlad, Carold Lasswell, John Dewey, Litle John, Onong Uchayana mereka menitik beratkan pada kajian face to face antara guru dengan siswa, namun saat ini para praktisi pendidikan sudah berubah pada pemanfaatan dan pengembangan digital. ${ }^{1}$

\footnotetext{
${ }^{1}$ Ishak Abdulhak, Deni dermawan.Teknologi pendidikan.(Bandung:PT roda Karya, 2013), 15
} 
Perkembangan pembelajaran yang awalnya menggunakan konsep tradisional yaitu tatap muka maka dikembangkan oleh para ahli dengan memanfaat teknologi informasi dan komunikasi berdampak besar bagi manusia. Perkembangan teknologi dalam pendidikan yaitu pembelajaran online dan offline. Pembelajaran online pembahruan pembelajaran dengan pengembangan media dengan koneksi pada jaringan internit. Bahan pembelajaran dapat divisualisasikan dalam bentuk yang lebih menarik dan dinamis. Dengan menggunakan berbagi variasi pembelajaran maka dapat meningkatkan antusiasme siswa pada pembelajaran. ${ }^{2}$

Pembelajaran online adalah model pembelajaran yang digunakan pembelajaran jarak jauh (distance learning) yang dilaksanakan sejak pada pertengahan tahun 1960-an oleh Universitas terbuka di Amerika Serikat dan di Inggris. Materi-materi seperti bentuk ceramah dan simulasi sudah di buat menjadi bentuk videotape kemudian dikembangkan dengan penggunaan internet, DVD dan $\mathrm{CD}$, membuat pembelajaran dengan menggunakan fasilitas video call guru dengan siswa sehingga memudahkan siswa belajar dan menjelajah pengetahuan. ${ }^{3}$

Namun pembelajaran online masih membutuhkan pembelajaran tatap muka yang disebut dengan blended learning yaitu memadukan antara pembelajaran online denga pembelajaran face to face. penelitian yang dilakukan oleh Dziuban, Hartman dan Moskal bahwa pembelajaran blended learning dapat meningkatkan hasil balajar serta dapat meningkatkan minat belajar siswa dibandingkan dengan pembelajaran penuh menggunakan pembelajran online. Serta ditemukan bahwa blended learning lebih baik di bandingkan dengan pembelajaran face to face seperti tabel berikut. ${ }^{4}$

\footnotetext{
${ }^{2}$ Sagala, Syaiful. . Konsep dan Makna Pembelajaran. (Bandung: Penerbit Alfabeta, 2006). 161

${ }^{3}$ Bruce Joyce, Marsha Weil, Emily Calhoun Model of Teaching. Yogyakarta:Pustaka Pelajar 508

${ }^{4}$ Charles D. Dziuban, Joel L. Hartman, Patsy D. Moskal, 2004. "Blended learning". Research Bulletin. Vol. 7, No. 1. March, 2004, 30.
} 
Tabel. 1Persentase nilai pembelajaran tatap muka, full online dan blended learning

\begin{tabular}{|l|l|l|l|l|l|l|l|}
\hline \multirow{2}{*}{$\begin{array}{l}\text { Pembelajaran } \\
\text { Tatap muka }\end{array}$} & \multicolumn{9}{|l|}{ Musim } \\
\cline { 2 - 8 } & $\begin{array}{l}\text { Semi } \\
2001\end{array}$ & $\begin{array}{l}\text { Panas } \\
2001\end{array}$ & $\begin{array}{l}\text { Dingin } \\
2001\end{array}$ & $\begin{array}{l}\text { Semi } \\
2002\end{array}$ & $\begin{array}{l}\text { Panas } \\
2002\end{array}$ & $\begin{array}{l}\text { Dingin } \\
2002\end{array}$ & $\begin{array}{l}\text { Semi } \\
2003\end{array}$ \\
\hline Tatap muka & 91 & 93 & 91 & 90 & 94 & 91 & 91 \\
\hline blended learning & 91 & 97 & 94 & 91 & 97 & 92 & 91 \\
\hline $\begin{array}{l}\text { Online Learning } \\
\text { (full) }\end{array}$ & 89 & 93 & 90 & 92 & 92 & 92 & 91 \\
\hline
\end{tabular}

\section{Kenapa harus blended learning}

Pemanfaaatan Information, Communication And Technology (ICT) dalam pendidikan sudah mengubah cara belajar dari pembejaran konvensional atau pembelajaran tradisonal yang mengedepannkan tatap muka menjadi pembelajaran yang berbasis digital dengan pemanfaatan teknologi dan informasi. Banyak pengembangan media pembelajaran yang berbasis digital yang memudahkan siswa untuk belajar mandiri sehingga menghasilkan pembelajaran online atau Pembelajaran offline.

Namun menurut Noer dalam Husamah bahawa pembelajaran online mempunyai kendala interaksi langsung antara peserta didik dengan pengajar bagaimanapun pengajar perlu feedback dari peserta didik dan peserta didik juga butuh feedback dari pengajar. Alasan mengapa pembelajaran online kurang memuaskan padahal materi sudah tersedia bisa belajara dimana saja karna peserta didik juga butuh interaksi dan interaksi langsung dengan pengajar. Sekalipun sekarang pembelajaran online juga dilengkapi dengan pengembangan video conference dan webchat siswa dengan siswa, siswa dengan guru butuh interaksi langsung satu sama lain. ${ }^{5}$

Blended learning merupakan solusi dari kelemahan-kelemahan dari pembelajaran online karena menggabungkan online, offline dan pembelajaran tatap muka. Pembelajaran online terdiri dari media yang dilengakapi dengan alat pengontrol yang digunakan oleh pengguna (user) sehingga pengguna (user) dapat mengakses adapun media oflline tidak dilengkapi dengan alat pengontrol yang dapat digunakan oleh pengguna (user)yang tidak perlu terkoneksi dengan jaringan internet misalnya materi bentuk tutorial dalam bentuk CD atau media yang sudah dibuat melalui aplikasi

\footnotetext{
${ }^{5}$ Husamah, Pembelajaran Bauran (Blended Learning), (Jakarta :prestasi Pustaka Publisher, 2014), 13
} 
yang bisa digunakan oleh siswa tanpa terkoneksi pada jaringan internet. Berbagai penelitian di berbagai fakultas oleh Mayes dan Marison dalam Jeffrey bahwa banyak guru tertarik dengan pembelajaran online namun Bates dan Sangra menambahkan begitu pula sebaliknyaan pembelajaran online sangat butuh pembelajaran langsung unutk memberikan feedback antara guru dengan siswanya. ${ }^{6}$

Pembelajaran dengan pengembangan teknologi dengan kombinasi pembelajaran tatap muka maka dapat dihasilkan suatu pembelajaran yang lebih efektif dan efisien. Pembelajaran ini seimbang antara tatap muka dengan pembelajaran online yaitu dengan menggunakan multimedia yang dimuat dalam komputer, handphone, konfeksi video dan media tekonologi yang lainnya. Tenaga pengajar dengan siswa dapat melakukan komunikasi sekalipun dengan jarak dan tempat yang berbeda dan juga siswa dapat dilengkapi dengan pembelajaran tatap muka yang memungkingkan terdapat permasalahan dalam materi pembelajaran online.

\section{Konsep Blended Learning}

Pada awalnya istilah Blended learning juga dikenal dengan konsep pembelajaran hiprida yang memadukan pembelajaran tatap muka, online dan offline namun akhir ini berubah menjadi blended learning. Blended artinya campuran atau kombinasi sedangkan learning adalah pembelajaran. Pendapat pula dinyatakan oleh Graham bahwasannya blended learning merupakan perpaduan atau kombinasi dari berbagai pembelajaran yaitu mengkombinasikan pembelajaran tatap muka (face to face) dengan konsep pembelajaran tradisional yang sering dilakukan oleh praktisi pendidikan dengan melalui penyampaian materi langsung pada siswa dengan pembelajaran online dan offline yang menekankan pada pemanfaatan teknologi. ${ }^{7}$

Menurut Musa blended learning adalah mengkombinasikan pembelajaran yakni pembelajaran E- learning atau online dengan pembelajaran tatap muka (face to face). Dengan pembelajaran online yang mana memanfaatkan jaringan internet yang di dalamnya terdiri pembelajaran berbasis web. Blended learning ini merupakan perpaduan dari pengembangan teknologi berbasis multimedia, CD ROM, video streaming, email,

\footnotetext{
${ }^{6}$ Ajeffrey, L.M. Milne, J, Suddaby. J.\& Higgins,"Blended Learning: How Teachers Balance the Blend of Online and Classroom Components", Journal of Information Technology Education:Research,. Vol. 13, 2014

${ }^{7}$ Antony G. Piccianon, Charles D, Dziuban, charkes R. Graham . Blended Learning Research Perspestive.(New york: Routledge, 2014), 4
} 
voice mail dll dengan menggabungkan pembelajaran tatap muka dikelas. Pembelajaran tatap muka memberi kesempatan pada siswa untuk menanyakan hal ataupun permasalahan yang berkaitan materi yang diajarkan oleh guru ${ }^{8}$

Pembelajaran online ini atau juga disebut pembelajaran jarak jauh yang mana guru/dosen dan siswa/mahsiswa dapat melakukan pembelajaran diluar sekolah/kampus sekalipun guru dan siswa tidak berada dalam satu ruangan atau tidak bertatap langsung. Guru memberi tutorial ataupun guru memberi tugas pada siswa yang mana sumber materi pelajaran bisa di akses di internet. ${ }^{9}$

Pembelajaran blended learning mengkombinasikan atau mencapur antara pembelajaran face to face dengan bantuan Information And Communication Technology ICT dengan mempunyai kelebihan-kelebihan yaitu

1. Siswa berinteraksi langsung dengan isi dari pembelajaran.

2. Dapat berinteraksi dengan teman.

3. Berdiskusi kelompok dan bertukar pendapat,

4. Mengakses e-library, kelas virtual.

5. Peniliaian online.

6. E-tuitions.

7. Mengakses dan memelihara blog pembelajaran.

8. Seminar online (webinars).

9. Melihat dosen ahli di youtube.

10. Belajar online melalui video dan audio.

11. Laboratorium virtural. ${ }^{10}$

Pembelajaran blended learning kombinasi berbagai bentuk alat pembelajaran misalnya kombina si real time perangkat lunak, program pembelajaran berbasis web online dan aplikasi lainnya yang mendukung pada lingkungan belajar dan pengetahuan manajemen sistem. Pembelajarran blended learning perpaduan antara online, tatap muka dan mandiri yang dipandu oleh mentor, guru atau dosen dengan pembelajaran yang terstruktur berikut gambarannya.

\footnotetext{
${ }^{8}$ Rusman, dkk, Pembelajaran Berbasis Teknologi Informasi dan Komunikasi, (Jakarta: PT RajaGrafindo Persada, 2011) , 242

9 Azhar Arsyad, Media Pembelajaran, (Jakarta:PT Raja grafindo Persada, 2013), 195

${ }^{10}$ Lalima, Kiran Lata Dangwal, "Blanded learning: an Inovative Approach". Universal Journal Of

Educational Reserch. Vol , 5. No. 1. 2017, 129-136
} 


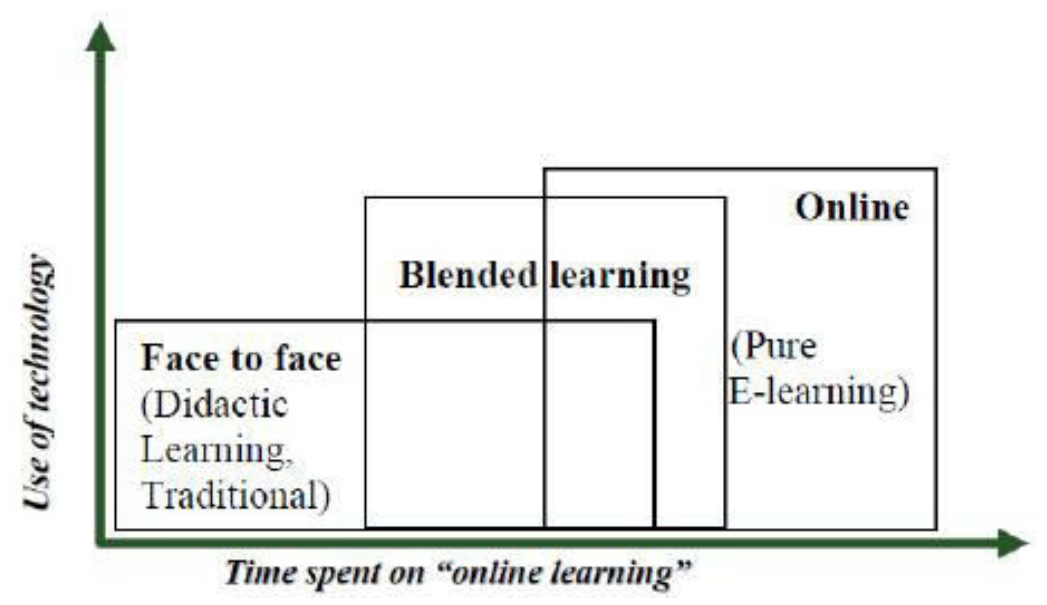

Konsep blended learning sumber: Henzi dan Procter (2004)

Pada tahun 2002, Driscoll mengidentifikasi empat konsep pembelajaran blended learning yaitu

1. Menggabungkan atau mencampur mode teknologi yang berbasis web misalnya kelas virtual langsung, pembelajaran kolaboratif, streaming video, audio dan teks.

2. Menggabungkan pendekatn pedagogis misalnya kognitivisme, konstruktivisme, behaviorisme, untuk menghasilkan pembelajaran yang optimal dengan atau tanpa penggunaan teknologi.

3. Menggabungkan segala bentuk te knologi pembelajaran misalnya video tape, CDROM, pelatihan berbasis web,film dengan dipimpin instruktur tatap muka.

4. Mencampur atau mengadukkan teknologi pembelajaran yang sebenarnya untuk menciptakan efek pembelajaran dan kerja yang harmonis. ${ }^{11}$

Komposisi blended learning yang sering digunakan yaitu dengan pola 50/50, dalam alokasi waktu yang tersedia 50\% tatap muka 50\% pembelajaran online, juga ada pula yang menggunakan pola $75 / 25$, artinya $75 \%$ pertemuan tatap muka $25 \%$ pembelajaran online, dan ada juga yang menerapkan 25/75, 25\% menggunakan pembelajaran tatap muka $75 \%$ menggunakan pembelajaran online. Dalam penggunaan pola tersebut tergantung dari analisis kompetensi yang dibutuhkan, tujuan mata pelajaran, karakteristik pebelajar, karakteristik dan kemampuan pebelajar dan sumber daya yang terssedia. Namun pertimbangan utama dalam merancang komposisi

\footnotetext{
${ }^{11}$ Ali alammary, Judy Sheard, Angela Carbone "Blended Learning In Higher Education: Three Different Aproaches” Australian Journal of Educational Technology, 2014, 30-40
} 
pembelajaran yaitu penyediaan sumber belajar yang cocok untuk berbagai karakteristik pebelajar agar pembelajaran menjadi menarik efektif dan efisien.

Prinsip-prinsip blended learning yaitu komunikasi antara pertemuan pembelajaran tatap muka dengan komunikasi tertulis online. Konsep pembelajaran ini terkesan sangat sederhana namun lebih komplek dalam penggunaannya. Maka dari itu perlu dilakukan oleh para pedidik dalam meningkatkan mutu pembelajarannya. Prinsipprinsip blended learning menurut Garrison dan Faughan dalam Husamah penggunaan yaitu :

1. Pememikiran dengan menggabungkan pembelajaran online dengan pembelajaran tatap muka.

2. Pemikiran ulang yang mana dalam mendesain pembelajaran ingin melibatkan siswa dalam proses pembeajaran.

3. Mengatur ulang pembelajaran tradisonal. $^{12}$

Dalam menggabungkan pembelajaran online dengan tatap muka yang disebut dengan blended learning beda dengan model pembelajaran lainnya. Blended learning juga mempunyai karakteristik tertentu diantaranya (1) proses pembelajaran yang menggabungkan berbagai model pembelajaran, gaya pembelajaran serta penggunaan berbagai media pembelajaran berbasis teknologi dan komunikasi, (2) perpaduan antara pembelajaran mandiri via online dengan pembelajaran tatap muka guur dengan siswa serta menggabungkan pembelajaran mandiri, (3) pembelajaran didukung dengan pembelajaran yang efektif dari cara penyampaian, cara belajar dan gaya pembelajarannya, (4) dalam blended learning orang tua dengan guru juga mempunyai peran penting dalam pembelajaran anak didik guru merupakan fasilitator sedangkan orang tua sebagai motivator dalam pembelajaran anaknya. Egbert dan Hanson smith berpendapat karakteristik blended learning yaitu siswa dapat bersosialisasi dengan baik dengan sesama, siswa mempuanyai waktu banyak dan dapat melakukan feedback, siswa juga dipandu dengan baik serta siswa belajar dengan atmosfer yang ideal. ${ }^{13}$

Unsur-unsur blended learning yaitu meliputi ranah pembelajaran online dan pembelajaran tatap muka. Unsur-unsur unsur tersebut meliputi (a) tatap muka dikelas (b) belajar mandiri, (c) pemanfaatan aplikasi (web), (d) tutorial, (e) kerjasama, dan (f)

\footnotetext{
${ }^{12}$ Ibid.., 5

${ }^{13}$ Ruchi Shivam, Sunita Sungh "Implementation of Blended Learning In Classroom: A Review Paper". Internasional Journal of Scientific and Research Publication, Vol. 20 , No. 1, November, 2015
} 
evaluasi. Guru berperan sebagai fasilitator dan mediator dalam pengelolaan unsu-unsur tersebut. Guru menjelaskan dan memberi arahan pada peserta didiknya bagaimana menggunakan aplikasi yang digunakan dalam pembelajaran. Guru juga memberi penjelasan materi sama seperti pembelajaran tatap muka namun guru hanya memanfaatkan media untuk tambahan materi atau untuk memberi tugas yang terstruktur pada peserta didik.

\section{Implementasi Blended Learning}

Model pembelajaran blended learning mempunyai tujuan untuk memfasilitasi terjadinya pembelajaran dengan menyediakan berbagai media pembelajaran dengan memperhatikan karakteristik siswa dalam belajar. Pembelajaran ini juga dapat mendorong peserta untuk memanfaatkan sebaik-baiknya kontak face-to-face dalam mengembangkan pengetahuan. Kemudian, tindak lanjut dari pembelajaran dapat dilakukan secara offline dan online. Program pembelajaran yang menggunakan full online kurang tepat digunakan untuk pembelajaran yang membutuhkan tatap muka antara pelajar dan pengajar seperti pada materi panjaskes dan materi lain yang memtuhkan praktek. Pembelajaran online efektif dilaksanakan apabila terdapat siswa yang berhalangan hadir, dengan pemanfaatan media online diharapkan siswa akan tetap bias mengikuti materi pelajaran.

Pembelajaran blended learning merupakan pembelajaran yang sangat efektif, efisien untuk meningkatkan kemampuan siswa menjadi menyenangkan, minat belajar siswa lebih besar dengan lingkungan belajar yang beragam. blended learning menawarkan pembelajaran yang lebih baik, baik terpisah atau kelompok serta waktu yang sama atau berbeda.

Penelitian yang dilakukan oleh Karen Precel, Yoran Eshet-Alkalai dan Yael dalam kontribusi komponen-komponen blended learning yang sangat berkontribusi dalam pembelajaran adalah tugas (rerata 4,72), buku cetak (rerata $=4,54$ ), presentasi pertemuan (rerata 4,42), dan pertemuan tatap muka dengan dibimbing instruktur (rerata $=4,14)$. Sedangkan hasil dari pembelajaran online yaitu memberikan konstribusi belajar $(3,83)$, buku online memiliki kontribusi untuk belajar rata-rata $(3,32)$ walaupun 
kontribusinya rendah hampir setengah dari peserta (46,5\%) menyatakan sering menggukannya. ${ }^{14}$

Selain data peneliatan diatas alasan juga kenapa menggunakan Blended learning ditambhkan oleh Osgusthorpe dan Graham learning blended learning dapat dilakukan oleh para guru, dosen, instruktur pendidikan pendidikan ada enam alasan yaitu

1. Kekayaan pedagogis,

2. Akses ke pengatahuan,

3. Interaksi sosial,

4. Agensi pribadi

5. Efektifitas biaya, dan

6. Kemudahan revisi ${ }^{15}$

\section{Penutup}

Dengan berbagai riset oleh para peneliti menunjukkan bahwa pembelajaran blended learning mempunyai pengaruh hasil yang tinggi di bandingkan dengan pembelajaran online dan tatap muka karna blended learning memadukan atau mencampur pembelajaran konvensional atau tradisonal dengan pembelajaran tradisonal dengan mengembangkan berbagai media pembelajaran. Blended learning merupakan solusi alternatif untuk menaggulangi kelemahan-kelemahan pembelajaran online dan pembelajaran tatap muka untuk menghasilkan rangkaian pembelajaran yang efektif, efisien dan menyenangkan bagi siswa dengan tidak membuang teori-teori pembelajaran lama.

Siswa yang masih belum melek teknologi bisa diajarkan di sekolah dengan cara diikutkan pelatihan-pelatihan dalam pengaplikasian teknologi. Pengusaan teknologi di Indonesia belum merata, karena luasnya wilayah Indonesia dan keterbatasan sumber daya, maka diharapkan pemerintah memberi investasi teknologi disetiap daerah dan memberikan pelatihan pada guru sehingga bisa meningkatkan mutu pendidikan Indonesia serta dapat menerapkan model pembelajaran Blended learning di Indonesia utnuk mempercepat dan mempermudah proses pembelajaran.

\footnotetext{
${ }^{14}$ Karen precel, Yoram Eshet Alklai and Yael "Pedagogical And Desain Aspect Of Blended Learning Course". International Review Of Research in Open and Distance Learning. Vol. 10, No. 2. ISSN: $1492-$ 3831 April 2009

${ }^{15}$ Graham, Charles R. (2006). Blended Learning Systems: Definition, Current Trends, and Future Directions. Dalam Bonk, C.J. \& Graham, CR.(Eds).(mpress)" Handbook Of Blended Learning:Global Persepektives, Local Designs. San Fransisco CA: Pfeiffer Publishing
} 


\section{Daftar Pustaka}

Ajeffrey, L.M. Milne, J, Suddaby. J.\& Higgins,"Blended Learning: How Teachers Balance the Blend of Online and Classroom Components", Journal Of Information Technology Education:Research, Vol, 13. No 2. 2014.

Alammary, Ali. Judy Sheard, Angela Carbone "Blended Learning In Higher Education: Three Different Aproaches" Australian Journal Of Educational Technology, 2014.

Azhar Arsyad. 2013. Media Pembelajaran. Jakarta: PT Raja Grafindo Persada.

Bonk, C.J. \& Graham, CR.Eds. Impress" Handbook of Blended Learning: Global Persepektives, Local Designs. San Fransisco CA: Pfeiffer Publishing

Bruce Joyce, Marsha Weil, Emily Calhoun. 1998. Model of Teaching. Yogyakarta:Pustaka Pelajar.

Charles D. Dziuban, Joel L. Hartman, Patsy D. Moskal. "Blended Learning”. Research Bulletin.Vol. 7, No 1. March 30, 2004.

Graham, Charles R. 2004. Blended Learning Systems: Definition, Current Trends, and Future Directions. Dalam Bonk, C.J. \& Graham, CR.Eds. Impress" Handbook Of Blended Learning:Global Persepektives, local designs. San Fransisco CA: Pfeiffer Publishing

Henzi, a, \& procter, C. 2004. "Reflections On The Use Of Blended Learning”, diakses dari .http://www.ece.salford.ac.uk/proccedings/papers/ah_o4.rtf. diakses pada tanggal 05 Mei 2018.

Husamah. 2014. Pembelajaran Bauran, Blended Learning, Jakarta : Prestasi Pustaka Publisher.

Ishak, Abdulhak. Deni dermawan. 2013. Teknologi Pendidikan. Bandung: PT roda Karya.

Precel, Karen Yoram Eshet Alklai and Yael "Pedagogical And Desain Aspect Of Blended Learning Course". International Review of Research In Open and Distance Learning. Vol,10. No, 2. April 2009.

Lalima, Kiran Lata Dangwal, "Blanded Learning: An Inovative Approach”Universal Journal Of Educational Reserch. 2017. 
Walib Abdullah, Model Blended Learning dalam Meningkatkan Efektifitas Pembelajaran

Ruchi Shivam, Sunita Sungh "Implementation Of Blended Learning In Classroom: A Review Paper”Internasional Journal Of Scientific And Research Publication, Vol,11. No, 2. November 2015

Rusman, dkk. 2011. Pembelajaran Berbasis Teknologi Informasi dan Komunikasi, Jakarta: PT Raja Grafindo Persada.

Sagala, Syaiful. 2006. Konsep dan Makna Pembelajaran. Bandung: Penerbit Alfabeta. 